\title{
A Study of Psychosocial Profile of Mentally Handicapped Children and Psychopathology in their Parents
}

\author{
Dr. Anup Rathi ${ }^{1 *}$, Dr. Mayur Muthe ${ }^{2}$, Dr. Anita Nagargoje ${ }^{3}$
}

\section{ABSTRACT}

Aim: To study the socio-demographic profile of mentally handicapped children and to compare the Psychiatric morbidity in parents of mentally handicapped children with that of parents of non handicapped children. Materials and Methods: The sample under study consisted of 50 children of both sexes 30 of these were mentally handicapped children \& 20 children were non handicapped. IQ was assessed using Coloured Progressive matrices and Goddard form board. SCID I was used to assess Psychopathology of parents. Results: The prevalence of consanguinity, pregnancy complications, co-morbidity (speech and seizure disorder) and psychopathology in mothers was high in mentally handicapped children as compared to non handicapped children.

Keywords: Mentally Handicapped Children, Mental Retardation, Psychopathology in Parents of Mentally Handicapped

At the beginning of this century, children suffered from a wide range of threatening medical illnesses, for which there was hardly any satisfactory treatment. Today, this situation has changed gradually but dramatically. Improved sanitation, diet and housing have led to general better health and resistance to diseases. Widespread introduction of vaccination programs has led to the decrease in the incidence of various diseases like polio, T.B. Small pox, etc. Improved neonatal care has reduced the incidence of birth handicaps.

It has long been established that disable and handicapped people are seen as 'different' from normal people, often being stereotyped as dependent, isolated, depressed and emotionally unstable. In turn, these public stereotypes lead to narrower range of role expectations and more restrictions on behaviors and opportunities for disabled people. Indeed, the major handicap of

\footnotetext{
${ }^{1}$ Assistant Professor, Dept of Psychiatry, Dr Ulhas Patil Medical College, Jalgaon Khandesh, Maharashtra, India

${ }^{2}$ Assistant Professor, Dept of Psychiatry, Dr Ulhas Patil Medical College, Jalgaon Khandesh, Maharashtra, India

${ }^{3}$ Assistant Professor, Dept of Psychiatry, Dr Ulhas Patil Medical College, Jalgaon Khandesh, Maharashtra, India *Responding Author
}

Received: January 18, 2017; Revision Received: February 20, 2017; Accepted: February 25, 2017

(C) 2017 Rathi A, Muthe M, Nagargoje A; licensee IJIP. This is an Open Access Research distributed under the terms of the Creative Commons Attribution License (www.creativecommons.org/licenses/by/2.0), which permits unrestricted use, distribution, and reproduction in any Medium, provided the original work is properly cited. 


\section{A Study of Psychosocial Profile of Mentally Handicapped Children and Psychopathology in their Parents}

disabled people is not their specific disability so much as the attitudes of general public towards them.

Children make large demands on society in terms of money and professional shifts the emotional problems of parents are no less daunting. In these conditions, the exact course \& time of deterioration may be unpredictable. Either ways parents have to cope with a treat deal of uncertainties about their child's health and future.

A common belief in this regards is that the presence of a disabled child has a negative effect on his family. This is one of the most common reasons cited to parents while recommending institutionalization for their child. This strongly indicates the negative attitude and avoidance of parents and society towards such children.

Hence, a study exploring this complex disability was taken up to understand the impact of child disability on Parents.

\section{Aim}

To study the socio-demographic profile of mentally handicapped children and to compare the Psychiatric morbidity in parents of mentally handicapped children with that of parents of non handicapped children.

\section{MATERIALS AND METHODS}

The sample under study consisted of 50 children of both sexes 30 of these were mentally handicapped children \& 20 children were non handicapped.

\section{Mentally handicapped}

30 mentally handicapped children of the same group of 8-12 years attending a special school for the mentally retarded were selected. Children with accompanying physical handicapped were excluded from the study.

\section{Non handicapped}

20 non handicapped children matched on socio-demographic variables were selected from the relatives accompanying patients to various OPDs in general hospital.

A Semi unstructured Performa was prepared and administered. Observations included: - Personal data, details about illness - severity of the handicap, co morbidity present, possible biological causes as mother's age at child birth, pregnancy complications, etc. 


\section{A Study of Psychosocial Profile of Mentally Handicapped Children and Psychopathology in their Parents}

\section{Instruments Used}

1. Intelligence Quotient in the subjects was assessed using the Colored Progressive matrices and the Goddard Form board.

2. SCID I was used to assess the psychopathology of parents.

\section{RESULTS}

\section{Socidemographic Profile}

Table 1: Age Distribution

\begin{tabular}{|l|l|l|l|}
\hline & $\mathbf{8 - 1 0}$ yrs & $\mathbf{1 1 - 1 2}$ yrs & Total \\
\hline Mentally Handicapped & $21(70 \%)$ & $9(30 \%)$ & $30(100 \%)$ \\
\hline Mild & 9 & 3 & $12(40 \%)$ \\
\hline Moderate & 12 & 5 & $14(56.60 \%)$ \\
\hline Severe & 0 & 1 & $1(3.33 \%)$ \\
\hline Non Handicapped & $13(65 \%)$ & $7(35 \%)$ & $20(100 \%)$ \\
\hline
\end{tabular}

On studying the age distribution of the 2 groups, 21 (70\%) of mentally handicapped \& 13 (60\%) of non-handicapped children were in the age group 8-10 yrs. Out of these 12 (40\%) had mild retardation, 17 (56.67\%) had moderate \& 1 (3.33\%) had severe retardation.

Table 2: Sex distribution

\begin{tabular}{|l|l|l|l|}
\hline & Male & Female & Total \\
\hline Mental Retardation & $17(56.7 \%)$ & $13(43.3 \%)$ & $30(100 \%)$ \\
\hline Mild & 4 & 8 & 12 \\
\hline Moderate & 12 & 5 & 17 \\
\hline Severe & 1 & 0 & 1 \\
\hline Non handicapped & $10(50 \%)$ & $10(50 \%)$ & $20(100 \%)$ \\
\hline
\end{tabular}

Out of 30 M.R. children 17 (56.7\%) of the retarded children were males \& 13 (43.3\%) were females. Amongst the non-handicapped 10 (50\%) were males \& 10 (50\%) were females.

Table 3: Type of family

\begin{tabular}{|l|l|l|l|}
\hline & Joint & Nuclear & Total \\
\hline Mental Retardation & $3(10 \%)$ & $27(90 \%)$ & $30(100 \%)$ \\
\hline Mild & 1 & 11 & 12 \\
\hline Moderate & 12 & 5 & 17 \\
\hline Severe & 1 & 0 & 1 \\
\hline Non handicapped & $4(20 \%)$ & $16(80 \%)$ & $20(100 \%)$ \\
\hline
\end{tabular}

On studying the type of family 3 (10\%) of mentally retarded, and 4 (20\%) of non-handicapped children belonged to joint family. The rest i.e. 27 (90\%) of mentally handicapped children \& 16 (80\%) of non-handicapped children belonged to nuclear family. 
A Study of Psychosocial Profile of Mentally Handicapped Children and Psychopathology in their Parents

Table 4: Consanguinity

\begin{tabular}{|l|l|l|l|l|}
\hline & Present & Absent & Total & P-Value \\
\hline Mental Retardation & $15(50 \%)$ & $15(50 \%)$ & $30(100 \%)$ & MR Vs NH P>0.05 \\
\hline Mild & 5 & 7 & 12 & \\
\hline Moderate & 9 & 8 & 17 & \\
\hline Severe & 1 & 0 & 1 & \\
\hline Non handicapped & $6(30 \%)$ & $14(70 \%)$ & 20 & \\
\hline
\end{tabular}

On studying the prevalence of consanguinity in these groups, 15 (50\%) of mentally retarded children \& 6 (30\%) of control were born of consanguineous marriage.

No significant different was found in the prevalence of consanguinity amongst the 2 groups.

Table 5: Mothers Age

\begin{tabular}{|l|l|l|l|}
\hline & $</=30$ & $>30$ & Total \\
\hline Mental Retardation & $23(66.66 \%)$ & $7(23.33 \%)$ & $30(100 \%)$ \\
\hline Mild & 8 & 4 & 12 \\
\hline Moderate & 14 & 3 & 17 \\
\hline Severe & 1 & 0 & 1 \\
\hline Non handicapped & $17(85 \%)$ & $3(15 \%)$ & $20(100 \%)$ \\
\hline
\end{tabular}

$23(66.66 \%)$ of mentally retarded and 17 (85\%) of non-handicapped children were born when mothers age was less than 30 yrs. whereas 7 (23.33\%) of mentally retarded \& 3 (15\%) of nonhandicapped were born when now these age was more than 30 yrs.

Table 6: Pregnancy complications

\begin{tabular}{|l|l|l|l|l|}
\hline & Present & Absent & Total & P-Value \\
\hline Mental Retardation & $15(50 \%)$ & $15(50 \%)$ & $30(100 \%)$ & MR Vs Control P $<0.05$ \\
\hline Mild & 5 & 7 & & \\
\hline Moderate & 9 & 8 & & \\
\hline Severe & 1 & 0 & & \\
\hline Non handicapped & $3(15 \%)$ & $17(85 \%)$ & $20(100 \%)$ & \\
\hline
\end{tabular}

Pregnancy complications were present in 15 (50\%) of mentally retarded and only 3 (15\%) of non-handicapped children.

Amongst the mentally retarded children 1 each only had prenatal or postnatal, 7 had natal, and 6 had more than 1 type of birth complications. In non-handicapped children, all 3 had natal complications.

The incidence of pregnancy complication was significantly more in mentally retarded as compared to non-handicapped.

(C) The International Journal of Indian Psychology, ISSN 2348-5396 (e) | ISSN: 2349-3429 (p) | 139 
A Study of Psychosocial Profile of Mentally Handicapped Children and Psychopathology in their Parents

Table 7: Co morbidity (Speech defect, Seizure disorder)

\begin{tabular}{|l|l|l|l|}
\hline & Present & Absent & Total \\
\hline Mental Retardation & $21(70 \%)$ & $9(30 \%)$ & $30(100 \%)$ \\
\hline Mild & 6 & 6 & 12 \\
\hline Moderate & 14 & 3 & 17 \\
\hline Severe & 1 & 0 & 1 \\
\hline Non handicapped & 0 & $20(100 \%)$ & $20(100 \%)$ \\
\hline
\end{tabular}

20 (70\%) of mentally retarded children while none of the non-handicapped children had medical co morbidity.

Amongst the mentally retarded children, 17 had speech defect, 1 had seizure disorder while 3 had both.

\section{Psychoathology in Parents}

Table 8: Fathers Psychopathology

\begin{tabular}{|l|l|l|l|l|}
\hline & Present & Absent & Total & P-Value \\
\hline M.H. & $9(32.1 \%)$ & $19(67.9 \%)$ & $28(100 \%)^{*}$ & MR Vs NH $>0.05$ \\
\hline N.H. & $4(20 \%)$ & $16(80 \%)$ & $20(100 \%)$ & \\
\hline
\end{tabular}

* 2 Fathers expired

Fathers of mentally retarded children had higher incidence of psychopathology as compared to fathers of non handicapped children.

Amongst father of M.H. children, 3 had dysthymia, 1 had anxiety disorder \& 5 had alcohol dependence. Amongst fathers of non handicapped children, 2 had alcohol dependence, 1 each had anxiety disorders and dysthymia.

On comparison of incidence of psychopathology in fathers, none of the group significantly differed.

Table 9: Psychopathology of Mother

\begin{tabular}{|l|l|l|l|l|}
\hline & Present & Absent & Total & P-Value \\
\hline M.H. & $18(60 \%)$ & $12(40 \%)$ & $30(100 \%)$ & MR Vs NHP $<0.05$ \\
\hline N.H. & $3(15 \%)$ & $17(85 \%)$ & $20(100 \%)$ & \\
\hline
\end{tabular}

On comparison, psychopathology of mothers of mentally handicapped children was significantly high as compared to mothers of non handicapped children.

Amongst mothers of mentally handicapped children, 12 had dysthymia, 5 had anxiety \& 1 had depression. Amongst the non handicapped group, 2 had anxiety and 1 had depression.

(c) The International Journal of Indian Psychology, ISSN 2348-5396 (e)| ISSN: 2349-3429 (p) | 140 


\section{A Study of Psychosocial Profile of Mentally Handicapped Children and Psychopathology in their Parents}

\section{CONCLUSION}

Mothers of handicapped children had higher psychiatric morbidity as compared to the mothers of non handicapped children; whereas the same trend was not observed amongst fathers.

\section{Acknowledgments}

The author appreciates all those who participated in the study and helped to facilitate the research process.

Conflict of Interests: The author declared no conflict of interests.

\section{REFERENCES}

Abramowitz Helen K, Rischardson Stephen A. Epidemiology of severe mental retardation in children Community Studies. American Journal of Mental Deficiency. 18-39

Blacher Jan, Meyers C E A review of attachment formation and disorder of handicapped children, American Journal of Mental Deficiency, 1989, 87 (4), 359-371.

Bonham Sharon Prince, Addison Susan: Families and mentally retarded children: Emphasis on father. The Family Coordinator, 1978 July, 221 - 230

Bradshaw Jonathan, Lawton Dorothy : Tracing the causes of stress in families with handicapped children British, Journal of Social Work, 1978 8(2), 181-192-

Byrne E.A. Cunningham C. C. The effects of Mentally Retarded children on families - A conceptual Review, Journal of Clinical Psychology and Psychiatry, 26 (6), 847 - 864, 1985

Channabasavanna S.M. Focus on the Mentally Underprivileged. Indian Journal of Psychiatry. 1985 April, 27 (2), 109 - 110

Chatuvedi Santosh K. Malhotra Savita: Parental attitudes towards mental retardation. Child Psychiatry Quarterly, 96 - 101

Crnic Keith A. et al : Adaptation of families with mentally retarded children: A model of stress, coping and family ecology. Indian Journal of Mental Deficiency, 1983, 88(2), 125 - 138.

Cummings S. T. The impact of child's deficiency on the father. American Journal of Orthopsychiatry, 1976 April, 46(2), 246 - 255

Fowle Carolyn M : The effect of the severely Mentally Retarded child on his family.

Friedrich William N. Et al. : Psychosocial Assets of parents of handicapped and non handicapped children. American Journal of Mental Deficiency, 1981, 85(5), 551 -553.

Girimaji R. Satish Chandra : Family intervention in mental retardation - An overview. NIMHANS Journal, 1993 January, 11(1), 21 - 26.

Jehan Kaisar et al.: Impact of parental education in the adjustment progress of their mentally retarded children, Child Psychiatry Quarterly, 153 - 156.

Mishra L.S.et al : Psychoclinical symptoms and factors associated with natal history of mentally retarded children. Clinical Psychiatry Quarterly, 162-167 


\section{A Study of Psychosocial Profile of Mentally Handicapped Children and Psychopathology in their Parents}

Nanda Shukla: Some probable factors causing mental retardation. Child Psychiatry Quarterly, $106-111$.

Narayan HS, Rao P Madhu, Subbakrishna DK, Rao BS Sridhara Rama: Observation of mentally retarded cases with special reference to consanguinity. NIMHANS Journal, 1987 July, $5(2), 121-123$

Pathak M.P. et al.: Some psychosocial factors associated with mental retardation. Child Psychiatry Quarterly, 116 - 122.

Prabhu GG: Special problems of the mentally retarded. Indian Journal Of Mental Retardation, 1968, 1(2), 87-94.

Wikler Lynn et al.: Chronic sorrow revisited: Parent Vs. Professional depiction of the adjustment of parents of mentally retarded children. American Journal of Orthopsychiatry, 1981 January, 51(1), $63-70$.

How to cite this article: Rathi A, Muthe M, Nagargoje (2017), A Study of Psychosocial Profile of Mentally Handicapped Children and Psychopathology in their Parents, International Journal of Indian Psychology, Volume 4, Issue 2, No. 92, ISSN:2348-5396 (e), ISSN:2349-3429 (p), DIP:18.01.115/20170402, ISBN:978-1-365-78192-6 